\title{
Gabriela Glăvan
}

\section{Communist Leftovers:}

\section{The forgotten Books of Gellu Naum}

\begin{abstract}
Although some of Gellu Naum's books from the 1950 s and 1960 s are frequently reissued (the two volumes of The Books with Apolodor), others are often avoided by critics and literary historians and dismissed as Naum's circumstantial attempts to acknowledge and follow the norms of socialist realism. This separation is the symptom of a divisive ideology that canonizes and rejects: the distinction between a major and a minor oeuvre generated, in this case, an irreconcilable separation that sidelined politically "tainted" writings, potentially depriving them of future critical rereadings. I intend to argue that their minority is worth revisiting - although aesthetically flawed and propagandistic, they reveal significant aspects concerning Naum's literary production in the 1950 s and early 1960 s.
\end{abstract}

Keywords: Children's Literature; Communism; Propaganda; Soviet Cultural Influence; Socialist Realism.

\section{GABRIELA GLĂVAN}

West University of Timișoara, Romania gabriela.glavan@e-uvt.ro DOI: 10.24193/cechinox.2017.33.11
Mlonul (The Lode) (1952), Tabăra din
munți (The Camp in the Mountains) (1953), Poem despre tineretea noastră (The Poem of our Youth) (1960) and Soarele calm (Calm Sun) (1961) are titles commonly associated with a dark period in Gellu Naum's long literary career. They are his "communist" books, bearing no relation or resemblance to his celebrated surrealist oeuvre. I intend to explore them in this paper and argue that they are relevant not only as distinct samples of the writer's protean creativity, but also as instances of literary (and political) survival, despite the obvious underlying contamination. My hypothesis is that they should function as integral parts of Naum's work; therefore, my aim is to challenge the assumption that their incongruence should doom them to irrelevance.

Gellu Naum's literary activity in the 1950s and early 1960s has long been regarded as an ideologically compromised intermezzo in his vast surrealist career; therefore, few critics seem eager to revisit it. With a few notable exceptions (The Book of Apolodor and The Second Book of Apolodor), Naum's socialist realist literature for children and youth and his proletcultist poetry have been gradually marginalized, 
exiled into the uncertain territory that Franco Moretti deemed " $[t]$ he great unread." There is a critical consensus that he is one of the most prominent figures of the Romanian historical avant-garde, and, probably, in Alistair Blyth's words, "the last of the Surrealists." Still, his socialist-realist poetry and books for children are yet to be critically explored in a coherent manner. Naum's temporary cultural collaboration with the Communist regime was hardly a rarity in the decades after 1945. Many writers gave in to the official doctrine and adapted their writing to the new political canon (Mihail Sadoveanu, Camil Petres$\mathrm{cu}$, Tudor Arghezi, to name just the most prominent ones). Later, Naum reneged on his socialist realist books and editors seem to have respected his wish. However problematic and difficult to integrate into the corpus of his oeuvre, they are an important part of literary history, worthy of further investigation.

A recent edition of Naum's Complete Works ${ }^{3}$ excludes the "circumstantial texts" of the 1950s (as they are called in the book presentation), and editor Simona Popescu provides no further motivation for the exclusion. In a study concerning Naum's beginnings, ${ }^{4}$ Popescu, suggests that, even if the writer was not allowed to publish his surrealist literature by the communist regime for several years, this period was marked by "a few editorial accidents." Although the critic does not mention the exact titles she refers to, it could easily be assumed that she refers to his literary excursions into social realism and communist propaganda. Eugen Negrici integrates this difficult period in Naum's activity into a larger frame, and he notes that "[f]ormer surrealists are also allowed to become active (as an implicit adhesion to the new cultural politics, emerging from the confusion generated by a so-called 'peaceful coexistence')." ${ }^{\prime}$ However, he bluntly discredits Naum's compromise: "After he had humiliated himself by publishing a volume adapted to the canon of the red aesthetics (The Lode, 1952), Gellu Naum decided to publish only translations and literature for children (So Is Sanda, 1956, The Greatest Gulliver, 1958, The Book of Apolodor, 1959). It is hard to understand today why he gave in and, in 1960, published a volume with the title Poem about our Youth, but those years of terror and indoctrination managed to exasperate many."

Both Filonul (The Lode) and Tabăra din munți (The Camp in the Mountains) are instances of propagandistic literature for youth. Naum's writings for children are still a huge success in Romania, his Books of Apolodor (two separate volumes of epic illustrated poetry) being republished frequently, in various formats. Although they belong to separate creative realms and have distinctive audiences, these works have been reunited under the uniformizing name of proletcultist literature and rejected altogether as aesthetically failed and politically tainted. My aim is to investigate the complex status these works have in Naum's oeuvre and explore some of their main themes, character types and literary strategies in order to delineate their particular territories. I intend to question the legitimacy of this specific type of exclusion and its potential consequences. Should literary history marginalize and exclude this type of literature in light of the devastating effects of communism? What can be learned and retained from these books regarding the social and political climate of their 
historical context? What could be lost if, after decades of being ignored, these books vanish from the literary spectrum of their age? What are the critical instruments and methodologies that allow a balanced perspective on the "literature of compromise" in communist Romania?

\section{Romanian Socialist Realism and Youth Literature}

$\mathrm{F}$ ranco Moretti's Hegelian metaphor of the "slaughterhouse of literature" 8 could easily be assumed as a profitable starting point in the investigation of Naum's communist books. What are the mechanisms that fuel the branch of the slaughterhouse where the uncomfortable, "unclean" books of otherwise important canonical writers fall into critical oblivion, morphed into nostalgic museum pieces or collector's items? Naum's literature for children and teenagers targets a specific audience - the "pioneers" (young communist comrades). Both Filonul and Tabăra din munți (The Camp in the Mountains) end with a brief note to readers, inviting them to write back to the editors and voice their opinions on "this book and its artistic qualities and design." On a friendly tone, the editors claim that they "would like to know your impressions about other books published by Youth Publishing [Editura Tineretului]. We would like to know if and how the books you've read helped you in any way. Please write us about the heroes you've befriended."

The educational value of children's literature has been vastly documented, and the particular case of socialist-realist books has been researched in connection with the influential Soviet tradition. Given the political and cultural domination of Soviet
Russia over communist Romania, the authority of this paradigm can be fully observed in the case of books for children and youth. ${ }^{10}$ In his comprehensive exploration of "Romanian literature under the communist regime," ${ }^{11}$ Eugen Negrici details the "sources of red aesthetics," 12 a "monstrous product of communist fundamentalism," ${ }^{13}$ a cultural framework that expressed "the Party's vision on literature in the years of integral Stalinism." ${ }^{14}$ Understandably, the seminal authors are the central figures of communist orthodoxy - Marx, Engels, Lenin, Stalin, seconded by others, such as Leon Trotsky (and his influential Literature and Revolution, of 1923), Andrei Zhdanov and Georgy Malenkov. Romanian party leaders often intervened on the subject of literature as an instrument of political education during the numerous congresses and plenaries of the period, and their speeches (edited by Leonte Răutu, the party's leading ideologist). Another "incomparable source of information"15 is Scânteia, the party's official publication. The sole purpose of socialist realist literature was "to prepare the soldiers of the Party."16 The new cultural direction fell on fertile ground, as well. Negrici outlines a brief explanation for its rapid success in Romania: "After 1944, the crypto-communist press organizations published luring articles that demanded a literature connected to reality. Quite many writers saw in this incentive an honest calling in the name of a necessary process of innovation of the artistic realm after years of formalism and abstract exercise. Such a suggestion was worthy to be embraced and, back then, it seemed like a reasonable suggestion - because the country had been through years of tragic war, a cruel drought and great social and ethnic dislocations; 
meanwhile, art had not expressed itself any differently, it had not welcomed the harsh present time and the threatening concrete, and it had not remained silent either." ${ }^{17}$

Russian children's literature, the prototype followed by the Romanian one, shares its ideals with all other Soviet literary genres - the education of mankind through exemplary world-views and aesthetic values. ${ }^{18}$ Felicity Ann O'Dell also describes the main characteristics of the didactic element in socialist realist books for adults, and all three of them can be easily identified in the context of children's books as well. Naum's two socialist-realist narratives that I intend to focus on shortly clearly follow this doctrine. The most notable characteristic of this literary formula is that all works must be optimistic and have a happy ending. ${ }^{19} \mathrm{~A}$ solid adherence to the canons of socialist realism implies that all artistic production must bear an ideological content ${ }^{20}$ and literature makes no exception. The educational component of children's literature also calls for a stronger emphasis on these unifying norms, as Naum's books visibly illustrate. The popular, unsophisticated nature of this type of literature relies on narratives detailing the everyday heroism of the social man. ${ }^{21}$ "Society rather than the individual is of central importance," ${ }^{22}$ and this principle is obviously reflected in both Filonul (The Lode) and Tabăra din munți (The Camp in the Mountains). Poem despre tineretea noastră (The Poem of Our Youth) and Soarele calm (Calm Sun) explore the idea of community through the vital bonds of comradeship and common communist ideals.

Education through literature was not a Soviet strategy, but rather a nineteenth-century one, as Marina Balina argues in a study on "The Beginnings of Soviet Children's Literature"23: "from the very early days on, the ideological agenda imposed on Soviet literature for children was hardly a creation of the Soviet propaganda system. Formed in the democratic revolutionary circles of the nineteenth century, the idea of 'ideinost' (ideological content) in the literary work as its first and foremost value was transferred into the postrevolutionary environment and applied to the whole body of literature, past and present, foreign and domestic." ${ }^{24}$ Balina invokes prominent nineteenth-century critics to support the argument that the educational value of "odetskoi" (children's) literature was acknowledged long before its ideological instrumentation. Vissarion Belinskii stated that "children's books are written for education, and education is an extremely important task: it decides the future of a human being." ${ }^{25} \mathrm{On}$ a similar note, Nikolai Dobroliubov considered children's literature "a textbook of life," as it prepares its readers "to resist life's evil... retain the purity of soul, and defend communal truth from lies, violence and self-interests." ${ }^{26}$ Looking back, Lithuanian critic Vincas Auryla considers the ideology-heavy children's literature of totalitarian regimes an "anomaly." ${ }^{27}$ Moreover, he deplores the fact that Soviet children's books are "left to rot on the libraries" 28 as they no longer have any readers. But Auryla asks an even more difficult question: "Why did talented writers cooperate with the regime, falsifying their books for young readers? How was the 'newspeak' of Soviet children's literature created, with words lacking meaning and social realism lacking realism? How did such concepts as humanism, patriotism, and internationalism mutate in children's 
literature?" 29 Eugen Negrici comes with a more trenchant diagnosis for the reason behind the writers' solidarity with the new political regime: "What characterizes intellectuals - and the N.K.V.D. knew this quite well - is the fact that their biological fear is accompanied and augmented by the fear of visibility loss." ${ }^{30}$ His conclusion is that " $[t]$ he Party vitally needed the propagandistic help of writers and, in order to accomplish that, it stopped at nothing." ${ }^{31}$

\section{Gellu Naum's Works for Pioneers}

$\mathrm{B}$ eyond the ethical question regarding motivation, there is a pragmatic necessity to decide if this rather massive corpus of books should be doomed to extinction or gradually rehabilitated on different grounds. Naum's case is no different, and a potential answer to Auryla's question (and to Negrici's speculative motivation) would be that collaborationism (even if literary) is often the symptom of a struggle for survival, not in the elementary sense, but the cultural (and editorial) one. There is a five year gap between Naum's last surrealist publications and his first proletcultist book, Filonul (The Lode). It is a 28-page long short story published in 1952, confirming the writer's forced departure from surrealism. His last avant-garde writings, published in 1947, were, quite significantly, collective works - manifestoes written together with the members of the Romanian surrealist group, Gherasim Luca, Paul Păun, D. Trost and Virgil Teodorescu (L'infra noir and Éloge de Malombra. Cerne de l'amour absolu; this latter manifesto was written together with Luca, Păun and Trost). Naum resumed his surrealist activity in 1968, when he published the volume Athanor.
Signed "G. Naum," Filonul was published by Youth Publishing (Editura Tineretului), and we can assume that its targeted audience were pioneers and young communists. A team of geologists, in search of a vein of ore in the Tibleșului Valley, near the Bran region, are simultaneously faced with the crisis of not finding its surface end and with the imminent danger of a powerful storm and wild animal predation. Flat and plainly descriptive, the narrative is all surface and no depth. An introductory paragraph presents the team and their mission:

It is almost certain that this vein is the end of the lode that they committed themselves to finding in honor of the great August holiday. Until yesterday, their team, led by Mihalea, hadn't found anything, although they had searched the valley far and near. The team of four geologists prospected in groups of twos: Mihalea and Tiberiu, and Zeceș with Condrea. When Zeceș discovered the "trace" and found its direction, it was already dark. Stars were twinkling above and the forest was barely visible, like a dark, uncertain spot at the end of the valley. ${ }^{32}$

Team effort and comradeship are predominant values, constantly reaffirmed throughout the narrative. The geologists are eager to do their duty and report back to the Institute in due time. Their enthusiasm derives from their impeccable work ethic (all communist enterprises praise exceeding the norm, and the geological institute is no exception) and from their devotion towards the Party and its seminal holiday - August 23 $3^{\text {rd }}$ (1944), when the Romanian army ceased to fight along 
Nazy Germany and allied with the glorious Red Army. Condrea, the youngest member of the team, is an emblematic figure of the young, determined, hardworking Romanian communist, devoted to the cause of a prosperous socialist future and loyal to his superiors. "One cannot take for granted the team leader's punctuality, not even up here in the mountains, ${ }^{33}$ Condrea thinks to himself. An unlikely encounter with Moș Vlad (Old Vlad), an elderly man from the nearby village facilitates further contrasts between the old world and the new one. While the old man warns the younger ones that mountain storms and wild animals can be dangerous, his advice is received with the skepticism of the brave and fearless. Old Vlad even confesses that he still celebrates "the old" holidays - "People keep telling me, but, well! Old age is the damnedest thing!" ${ }^{34} \mathrm{He}$ also admires the eagerness of the geologists and transparently expresses his approval of the new order - "I reckon there's a great holiday the day after tomorrow if you're ready to beat the storm just to honor it..."35

Condrea had made a promise to his colleague Gheza, the leader of the foundry brigade from Baia. The night before their departure on their mission in the mountains, Gheza encouraged the team with typical communist formulas: "I look forward to welcoming you back so that we can celebrate together our holiday ad I wish you great success in your work. Do not forget that we need as much ore as possible, so that we can exceed our plan." ${ }^{36}$ The great ideological shift is visible on an essential level - old religious rites have been exchanged for new political ones. And the faithful participate in the festivities, bringing in new converts - their children. Zeceș laughs when he reminisces that, the year before, he took his son with him to the parade - "He was four years old and I carried him on my back. You should have seen his joy!"37 Party ideology permeates social interactions to such an extent that, during an argument with his colleagues, Zeceș firmly declares: "Look, I was taught by the Party to tell things as they are." ${ }^{\prime 3}$ The mission is successful and the team find the lode in time for the August $23^{\text {rd }}$ celebration. They triumph over nature as the ending clearly states - the gigantic bear that watches them every night from a distance is still there, by the edge of the forest, somehow scared and defeated.

Filonul is definitely a sample of ideologized educational literature and it massively relies on the socialist realist prototype outlined above. Social man abandons his individual needs, and he overcomes his crises and fears in order to embrace the higher ideal of the group and of society. Young pioneers are presented with a tale of communist ethics that could offer them direction and guidance in a comprehensive manner, as it reunites paradigmatic elements of propagandistic formative literature - work as a supremely noble mission that must be accomplished against all odds, in a manner reminding of archetypal spiritual quests; the new world and its new political order entails a fundamental shift in values and beliefs ${ }^{39}$ - the "old holidays," as Old Vlad calls them, have been replaced by the new ones, signaling triumphant moments in the history of communist conquest; much like monotheism, ${ }^{40}$ communism emphasizes the role of a singular prophetic leader, whose mission is to guide his fellow men on their journey to enlightenment (disguised as progress) - here, the 
leader is Zeces, who not only manages to trace the vein of ore, but also critically interrogates his colleague Tiberiu, who seems reluctant and uninvolved:

Specialists of your kind resemble damn well this shawl. They are eaten away by old ideas, just like it would be eaten by moths. You must shake them off really well, otherwise, look, you would do just as you did today, stand in our way. And we won't let you. Try to get a good grip and then you'll be able to understand a lot of things, for example where did your hesitation and fear come from and where does our strength come from. ${ }^{41}$

Although both Filonul and Tabăra din munți were specifically written for teenagers, the latter, published in 1953, resembles an adventure story with pioneers on their summer holiday. Despite its educational framework, Filonul hardly resembles the classical discursive format of children's literature, while Tabăra din munți follows it closely. Once again, Naum signed his book "G. Naum" (the author signed his surrealist books in his whole name). However, it is difficult to tell if this could be interpreted as a strategy of auctorial dissimulation. In a 2003 interview with Lygia Naum (by Sveltana Cârstean), the poet's wife expressed the rather surprising opinion that Tabăra din munți cannot be considered a concession to the official regime: "He did not make concessions. Not even the reportage The Camp in the Mountains could be considered a concession. Without this text, he wouldn't have been allowed to join the Union [of Writers], as wouldn't have been 'admitted' with The Incendiary
Traveler, The Terrible Forbidden or Medium. He had been told that 'these are not books to join the Union'." However, he wouldn't have been allowed to publish translations if he hadn't joined the Union." ${ }^{42}$

Tabăra din munți is an illustrated book detailing the summer camp adventures of Vasile, a twelve year old boy from Bucharest, in the summer of 1950 . The beginning of the narrative is dynamic and fast paced: Vasile bids his home friends farewell and embarks on a journey to the mountains, where he would make new friends in new, exciting circumstances. Both characters and contexts are didactic and predictable. Vasile keeps a diary where he writes his impressions about the camp, the people he meets, the challenges he faces. Dogmatic terminology becomes the norm from the earliest stages of the narrative - the children are no longer called children, but "pioneers," even if the notion is artificially inserted in unsuitable contexts. A relevant scene occurs on the train, on the way to the camp, when the teacher in charge of Vasile's group notices that Ștefănică, a younger pupil, got lost and couldn't be found, so he asks other travelers if they had seen "a pioneer of short stature, with blue eyes." ${ }^{33}$ Significantly enough, the first activity on the camp agenda is to group the participants according to the generic structure of the pioneers' organization, with group and brigade commanders, replicating the same structure and hierarchy imposed in schools. The camp is, in fact, a political training facility, with Lenin and Stalin's pictures on the walls of each dormitory: "The room Vasile had entered had white walls, with beautifully framed portraits of Lenin and Stalin." 44

The voluble, energetic Vasile makes friends easily, but also has an opponent in 
the new group - Stere, an orphan boy who displays visible signs of childhood trauma and loss. Lonely, cynical, aggressive, Stere is a transparent character ready to be converted. Indeed, by the end of the book, what seemed at the beginning like and impossible connection turns into a surprising friendship, as Vasile and Stere become pals and share a special bond. The social once again triumphs over the individual, and the ethics of comradeship proves effective in alleviating old family traumas.

Indeed, Tabăra... is not a sample of Naum's literature for children, it is educational literature for pioneers. The narrative relies almost exclusively on conformity and normative didacticism, as characters constantly seem to learn lessons about themselves and about others. Children's games are not imaginative and free, but educative and moralizing. The Soviet model is once again detectable in the complexity of the plot - the young pioneers learn how to face danger and defend the communist cause, they internalize the values of the official party doctrine and obey their superiors, they are proud of their status and constantly reiterate it socially, in the most unlikely circumstances. They are active, helpful and available to help others, yet they are aware of the presence of enemies - they denounce saboteurs and the kulak, people of the old order who exploited peasants and were capable of murderous deeds. They improvise a small construction site, where they start building a little bridge, and they plan to help. While Vasile enjoyed his status as group commander, when he is faced with the responsibility of the site, he takes a moment to meditate on the significance of his status. His monologue is relevant for the artificial articulation of formulaic ideology: "He was confused. Until then he was happy he had been elected commander, but he was just glad and that was it. It is nice to be group commander. When somebody asks 'Who's in charge?,' you briefly answer 'I am,' and you also ask them if there's anything you can do, while the others remain silent, as they should. And then, out in the square, you order loudly: 'Group, attention!' and that is also very good. And when you get home and school starts, you boast: 'In summer camp I was group commander and my group went perfectly well, it was first in the brigade, and, to tell you the truth, even first in the unit!"'45

The "scientific mythology" of communism, as Lucian Boia ${ }^{46}$ termed the communist obsession for science (and, implicitly progress) is reflected in the educational context of the book through the specific task of Vasile's team - they are "the naturalists," and their mission is to observe and study wild plants and animals in the forest; they collaborate with the group of "crafty hands" - pioneers who manufacture artisanal objects and devices. When they find out that a new school was going to be built in the village near the camp, they plan to donate it all the materials they gathered during the camp. They befriend Bălănel, a boy from the village who comes from a modest family of peasants (workers and peasants were privileged in communism due to their "clean" origins) and who is viciously attacked in the forest by an opponent of the regime - he believes his attacker was Melinte, one of the last kulaks in the region.

Teachers and parents are constant authority figures in the book, and they constantly lecture and give advice. Vasile remembers that his father had told him 
stories from his factory, where dangerous saboteurs of the prosperous new political order would undermine production and cause serious damage. The iconic Pavlic Morozov $^{47}$ is invoked in this context: "What do you think, that the enemies are sleeping? My father told me a story about some kulak who had set fire to a materials warehouse. And was it not them who killed Pavlic Morozov, too?" 48 Echoing Pavlic, Bălănel has a better fate - although severely wounded, he is treated in the hospital and recovers completely. Comrade Simion, the teacher who is their camp instructor, tells his pupils stories about Soviet pioneers from Ukraine, who fought the drought and, through constant effort and hard work, managed to "plant over six and a half million trees" 49 and they watered them with buckets they carried themselves. Comrade Radu, the principal of the camp, tells them stories about Korea and its brave people: "Children - he told us - far away from our country, to the east, there is an ancient peninsula, covered by old mountains, crossed by silver rivers. A peaceful and proud people lives there, freed by the glorious Soviet Armies, just like we were."

When summer camp ends and the pioneers prepare to go back home, they make a bonfire and celebrate the moment by singing "under the star lit sky, the pioneer song We Thank the Party with All Our Heart." ${ }^{51}$ Vasile, Alexandru, Voicu, Mustață, Gâdea, Ștefănică, Stere and Neagu promise each other to write, have good results in school and honor their allegiance to the Party. The narrative ends on a dynamic, positive note - reunited with his family, Vasile tells them what he learned, who he met, what good deeds he did. There are no uncertainties, no mystery, no shadows on the clear blue pioneer horizon.

\section{Poetic Journeys to the Red Continent}

Cellu Naum's two volumes of poetry $\checkmark$ written outside of (and, possibly, in spite of) the realm of surrealism, were published almost a decade after Filonul and Tabăra din munți. Poem despre tinerețea noastră (The Poem of Our Youth) was published in 1960 , by the same publishing house that launched his two previous socialist realist books - Editura Tineretului (Youth Publishing). Illustrated by Jules Perahim, a former surrealist painter with whom Naum had collaborated when he published the first edition of The Book with Apolodor, in 1959 , the book greatly benefits from this artistic dialogue, despite its problematic content. Perahim's visions in black and white add a strong element of visual drama, complementing the harsh tonality of Naum's poetry. The volume reunites sixteen poems of various length, and the first one, entitled "Back Then," implies a recalibration of the past meant to revive old myths in light of present concepts: "I should probably start by reminding/ of the boat with silvery oars/ chasing the golden fleece in dreams/ I should probably remind you/ of the magical, unforgettable words/ the three bewildering words: bread, love, liberty." 52 Youth is a time of revolution, and its language is as clear as the laws of science: "There would be the wonderful breeze/ and the tremble of the clear blue sky/ but your youth demands/ the rough and rigorous language/ of elementary mathematics." ${ }^{53}$ The epic flow reveals undeniable contrasts between a gloomy, exploitative, bourgeois past, and the fair, egalitarian present: "Back then, in factories/ the day used to be fragmented in hours of exhaustion/ and the 
hours in seconds of anger;/ back then, in factories,/ the hearts of men, like secret fires/ were preparing the lights of battle." ${ }^{54}$

The difficult life of peasants is invoked repetitively as an exemplary instance of the failure of the old world order: "Back then, some students - over-learned/ holding their fist-sized skulls/ under velvet caps/ dancing shimmy/ discovering the criteria of the tragic/ in the hunch of the brothel pianist." ${ }^{55}$ Provocateurs, saboteurs, agents and Hitler himself create a despicable parade that the Pope looks on admiringly, but "against them, back then/ Lenin's word was humming/ as future forests hum in the acorn of oaks." ${ }^{56}$

The theme of youth is presented directly, as an invocation - "Oh, My Youth" is a lamentation deploring the poverty and precariousness of young age in the old world. An emphatically titled poem, "Human Condition," focuses on the element of hands, another fetishized element of communist iconography. Hands and arms are stylized in the classical manner of propaganda aesthetic austerity: "Hands projected to sow bread and flowers/ hands made to cradle infants/ and the hands of maidens, like marble balconies/ the hands that we'd touch our heads with/ in the desperate hours of love/ and the young, powerful hands/ that made the air vibrate with their touch/ hands that would extract, from earth's deep sleep/ gigantic waves of coal. ${ }^{157}$ Hands, as universal agents of work and order, are unifying elements that bring together individuals that would not be reunited in the old, individualistic world: "I speak of the black hands of miners/ the white hands of weavers/ the harsh hands of tinkers/ the hands of locksmiths and poets/ the hands of hacks and laborers/ the hands that clenched back then:/ I speak of the powerful hands of communists/ and the hands of those in U.C.Y. ${ }^{58}$ t the hands of our youth/ building the barricades of human dignity." ${ }^{59}$

The abandonment of individuality is proclaimed in unambiguous terms: "the power to feel, when you imagined yourself a leaf in autumn trees/ that you are bound to others with strong ties/ the lamp that lights the fog, towards the dream/ they were all given to us/ by the Party." ${ }^{\prime 6}$ Declamatory poetry, like religious hymns, revisit the sacred history of the dogma, revealing the mythological struggle between the forces of evil and the new man, guided by the Party. The poem "Listen" is an exemplary instance "this day back in February 1933/ listen how the Party calls them to battle/ listen how it answers, like a forest of echoes/ the heart of our youth/ listen up, listen..." ${ }^{61}$

Sleep and dreams, the predilect territories of surrealism, no longer serve imaginary enterprises, but real, political ones. Instead of passively lying asleep, young communists disseminate manifestos in $\mathrm{Bu}-$ charest at night: "They were stepping slowly/ carrying in them the vigor of youth/ and the grimness of times to come/ they were stepping slowly/ feeling the dense reality of danger./ Deep waters of sleep were flooding/ all houses/ but the sleep of people/ - even their sleep -/ was divided/ and every man/ would travel in his body as if on a boat. [...] But I will say/ That they were stepping slowly/ in the trap-filled city night/ leaving on each threshold, on each wall/ the imprint of the dawn/ they were slowly stepping by the sleep of tiredness/ and they would bring along/ words of awakening." ${ }^{\prime 2}$ 
The declamatory nature of propagandistic poetry contaminates the poetic language of the volume in a crescendo, with stronger accents in the final cycle of poems. "The Thirst to Be United" is a clear sample of activist literature, fully reflecting the official directive of socially and politically involved poetry: "I will say what other have not forgotten/ I will say that hate begun where fear ended/ I will say that hunger started where hunger ended/ I will say that bars began at factory windows/ I will say that parting started in the arms of the beloved./ I will say that night began where night ended/ night of camps, night of barracks, night of prisons." ${ }^{63}$ An inherent opposition with the old lyrical paradigm becomes apparent in the poem "Of Course, Tulips Were Blooming." The decadent aesthetics of the past is once again condemnable and blind, unaware of real pain and feelings. The indifferent, artificial contexts of pastels and ballads appear in dire opposition to the harsh reality of political torture, beatings and arrests: "Of course, tulips were blooming in gardens/ but in the basement of the prefecture, in cells/ the wall would tremble as our comrade groaned/ as he had just be brought to be questioned;/ Of course, orchestras were playing in gardens,/ and trees would rustle, for fiddlers' sake/ and the sky would be filled with stars/ while in the basement of Security/ tortured soles would leave streaks of blood/ and bodies would falter like aspens blown by winds..." ${ }^{64}$ The power of poetic language seems more real than ever before, more active and involved, as it has assimilated the progressive terminology of propaganda: "our ears would sadly turn away/ each time mechanical mouths would sing hymns - but like snowflake flowers trembling beneath ice/ words of action, words/ from the secret arsenal of our youth: Lenin, Party, Freedom..."65

Activist literature is often narrative, defying the classical norms of metaphoric hermetism. "The Death of the Partisan," just as the title states, is the story of glorious partisan opposition in the face of death: "At dawn, they said/ - Wake up; the time has come.../ And he replied: - Death to all executioners!/ And then he saw the matte glare of the bayonets/ the ghostly shape of a tree/ the city streets, engulfed in fog./ On the road, they said:/ It's not too late if you decide to speak.../And he replied: Death to all executioners!"66 The sixteenth poem, and the last, is an ample epic reloading the main themes of the volume in the shape of an artistic creed. "Golden Words" quite transparently proclaims the dogmatic affiliation of poetry to the official ideology and could be considered a relevant sample of political theology. As Eugen Negrici pertinently argued, the "political religion" of communism "acted just like any religion in its fundamentalist stage." ${ }^{67}$ Moreover, Negrici notes that one of the most proficient (and rather unexpected) emotions that patriotic poetry relies on is hate. Quoting from a poem by Eugen Frunză ("Hate! Hate! As nothing's more sacred/than hate guarding life on earth"), ${ }^{68}$ Negrici considers that "the drug of hate and envy" ${ }^{69}$ was a powerful instrument involved in class struggle. Naum's closing poem revives the central allegory of youth and connects it to a vast reserve of hatred: "With the lightning of the thousands and thousands of eyes/ of our youth/ with all the hate, the acerb hate that we've kept/ just like others would cherish a jew$\mathrm{el} /$ we'd like to poke the retina/ of these round eyes" 70 The ending is triumphant as it reveals the "golden words" meant to guide 
everyone to a luminous future: "with all the voices of our youth/ we solemnly affirm, no end in sight/ the golden words: Lenin! The Party! To communism!" 71

Soarele Calm (Calm Sun) was published in 1961 by Editura Pentru Literatură (Literature Publishing) and it reunites five chapters of poems, illustrated by Jules Perahim. More complex than Poem despre tinerețea noastră, Soarele calm integrates Naum's ideological stance in a vaster poetic project. The opening poem, "Un sigur lucru" (Only One Thing, which is also the title of the first group of poems) is a declarative first person confession similar to others included in Poem. The omnipresent reference to a difficult past is once again used as the starting point of a new poetics: "some other times I dress my verses in a frock coat/ and their silhouette bores me to death;/ this is not a game, of course,/ or, anyway, it is an extremely severe poetic game,/ but in my still darkling quests/ one thing is certain:/ I do not easily forget the gloomy gangways of the past,/ nor the dark shadow of the $\mathrm{dog} /$ and I keep close watch with other living men,/ so that night never reflects again in the serene eyes of children. ${ }^{72}$ History is the overarching theme of an ambitious epic poem entitled "Primăvara lumii" (Spring of the World), debuting on a harsh tone that blames and exposes those who "like to look in the past/ as is through I don't know what king of magic lens/ and rummage it like a sock full of money." ${ }^{73}$ Naum draws a different map of days gone by and signals the most relevant moments that have come to define the present - therefore, "nineteen seventeen" ${ }^{\prime 4}$ was the year of war, and "father had been a poet. And was rotting away/ somewhere beneath the trenches." 75 This biographical element is the starting point of universal revolution: "my father's bones, rotting away on a field,/ these bones, like wet flutes/ have been singing in my ears each spring;/ and from them, and from millions of tired others,/ from millions of stormy hopes,/ from millions of chests, from pure hate,/from millions of hearts, from millions of dreams, / that year, a giant flame emerged,/ an unbelievable spring:/ The spring of October had started. ${ }^{76}$ Other important dates structure this personal and ideological account - "March, nineteen twenty-two," 77 "oh, Bucharest of thirty-three,"78 "the years of crimes," 79 "March, nineteen forty," ty-two," "A1 "April, forty-four," 82 "when the name of death was LILY-MARLEN," then "spring, nineteen forty-nine," ${ }^{84}$ when "the saps of spring kept going up," and the world order was changing, the monarchy "burst/ like a bubble of soap it burst." ${ }^{85}$ March, nineteen fifty-five (the present moment of writing) is the year of nuclear arming, and of the capitalist remnants of war, still lurking, as "Mr. Krupp has a new little hall/ with uranium electric chairs, covered in leather,/ human skin, black or white, human skin, just like yours...)/ Mr. Ford enjoys his siesta, in peace/ $\mathrm{Mr}$. Dupont de Nemours/ installed electric brains in each city,/ and now dreams of building a drum/ (a human skin drum, black or white, made of human skin, just like yours)/ a hydrogen drum/ dreams of beating it and setting off an attack/ dreams of singing LILY-MARLEN." ${ }^{\prime 6}$ The ending is one long, idealist patriotic exhortation: "Keep all your hopes/ and dreams of love, of freedom./ be tough! Keep them pristine! Spring will be yours, too!" 87

Naum's poetic project shifts back to an old propagandistic favorite trope - the 
village, the life of peasants, the purity of nature, the place of new beginnings and founding myths. The Village Journal, the second chapter of the volume, marks an interesting deviation from the first part, as it accentuates the traditional dimension through the means of classical rhyme. The austere atmosphere of the secluded countryside is also the haven of essential events, such as the birth of a calf, the revelation of the impossibility of God and religion, the growth of plants, the fertility of earth. However, the poetic effort to conceptualize the new political reality sometimes generates involuntary humorous effects: the final verses of "Plutirea timpului" (The Floating of Time) refer to "a poem/about party politics in the countryside," 88 "Greu..." (Difficult...) infers that God revealed himself to an illiterate old woman "in new tennis shoes/ from the co-operative...," 89 and the final poem of the series, "Lights," ends with an uncanny rhyme that reunites the celestial with the communist mundane: "we each were given, from the mill/ full moons that shine, forever, still." 90

The only non-ideological chapter of the volume is Cântece de dragoste pentru Lygia (Love Songs for Lygia), a lyrical intermezzo that reveals the poet's love for his wife. Traditionally coherent, relying on classical rhyme and romantic imagery, the poems of this chapter radically differ from Naum's surrealist exploration of the theme of love in future volumes. The final two chapters, Exercitii (Exercises) and Alergătorul (The Runner) are interesting attempts at tackling innovative poetic strategies. Although they facilitate the return of some surrealist themes - reveries, stylistic digressions and narrative parentheses, exotic, unreal landscapes and archetypal characters - there are also frequent references to "another kind of beauty, unseen before," announcing the dawn of a glorious new era.

\section{Conclusions}

$\Lambda$ critical rereading of Gellu Naum's so1 cialist realist poetry and youth books is a necessary step towards a coherent understanding of a difficult and problematic literary history issue - the writers' collaboration with the communist regime. A balanced approach should avoid, for the sake of critical distance, solidarity with the author's dismissal of his ideologically compromised works. The red aesthetics is a complex cultural phenomenon that can reveal many facets of a dramatic decade that established an enduring tradition in Romanian literature. The 1950s and early 1960s, when Naum published his four works discussed above, lay the groundwork for a solid, essential genre of the communist era, propaganda literature. The author's partial inclusion in this paradigm is a stimulating challenge for researchers of the period and of Naum's work, as well. 


\section{BibLIOGRAPHY}

Auryla, Vincas, "Children's Literature in Totalitarian and Post-Totalitarian Societies," in Sandra L. Beckett, Reflections of Change. Children's Literature Since 1945, Greenwood Press, Westport, 1997, pp. 177-182

Balina, M., Rudova, L. (ed.), Russian Children's Literature and Culture, New York, Routledge, 2008

Beckett, Sandra L., Reflections of Change. Children's Literature Since 1945, Westport, Greenwood Press, 1997 Blyth, Alistair, The Last Surrealist. Preface to Gellu Naum, Vasco da Gama and Other Pohems, Bucharest, Humanitas, 2007

Cârstean, Svetlana, interview with Lygia Naum, "Whatever he does can only be beautiful," Observator cultural, March 11, 2003, available online http://www.observatorcultural.ro/articol/orice-face-el-nupoate-fi-decit-frumos-ii-interviu-cu-lyggia-naum/, accessed January $12^{\text {th }}, 2017$

Dunea, Ioana, O privire necesară asupra poemelor comuniste publicate de Gellu Naum (A necessary look at the communist poems published by Gellu Naum), available online http://www.poetic.ro/19-02-2012-o-privirenecesara-asupra-poemelor-comuniste-publicate-de-gellu-naum/, accessed January $10^{\text {th }} 2017$

Livescu, Cristian, "Gellu Naum, precursorul incendiar" (Gellu Naum, the Incendiary Precursor), Convorbiri Literare, February $12^{\text {th }} 2016$, available online http://convorbiri-literare.ro/? $\mathrm{p}=5714$, accesed January $5^{\text {th }} 2017$ Medvedeva, N. "Russian Children's Literature on the Contemporary Stage," International Library Review, 1971, vol. 3, no. 2, April 1971, pp. 133-140

Moretti, Franco, "The Slaughterhouse of Literature," $M L Q$, March 2000

Negrici, E., Literatura română sub communism. 1948-1964 (Romanian Literature in Communism. 19481964), Cartea Românească, Bucharest, 2010

O'Dell, Felicity Ann, Socialisation Through Children's Literature: the Soviet Example, Cambridge University Press, 1978

Naum, Gellu, Filonul (The Lode), Editura Tineretului, Bucharest, 1952

Naum, Gellu, Tabăra din munți (The Camp in the Mountains), Bucharest, Editura Tineretului a C.C. al U.T.C., 1953

Naum, Gellu, Poem despre tinerețea noastră (The Poem of Our Youth), Bucharest, Editura Tineretului, 1960 Naum, Gellu, Soarele calm (Calm Sun), Bucharest, Editura Pentru Literatură (Literature Publishing), 1961 Popescu, Simona, Salvarea speciei. Despre suprarealism şi Gellu Naum (Salvation of the Species. On Surrealism and Gellu Naum), Bucharest, Editura Fundaţiei Culturale Române, 2000

Popescu, Simona, Clava. Critifiçtiune cu Gellu Naum. (Clava. Critifiction with Gellu Naum), Piteşti, Paralela 45, 2004

Preda, Simona, Patrie Română, tară de eroi! (Romanian Homeland, Country of Heroes!), Bucharest, Curtea Veche, 2014

Ungureanu, Cornel, "Despre salvarea speciei" (On the Salvation of the Species), România literară (Literary Romania), no. 34/2011, available online http://www.romlit.ro/despre_salvarea_speciei, accessed January $16^{\text {th }}, 2017$

\section{NoTeS}

1. Franco Moretti, “The Slaughterhouse of Literature," MLQ, March 2000, p. 225.

2. Alistair Blyth, The Last Surrealist. Preface to Gellu Naum, Vasco da Gama and Other Pohems, Bucharest, Humanitas, 2007.

3. Gellu Naum, Opere I. Poezii (Complete Works I. Poems), Iași, Polirom, 2011.

4. Simona Popescu, "Gellu Naum's 'Beginnings' (Which are Dead Ends)," Dada/Surrealism, no. 20, number $1 / 2015$.

5. Ibid., p. 2.

6. Eugen Negrici, Literatura română sub comunism. 1948-1964, Cartea Românească, Bucharest, 2010, p. 204. 
7. Ibid.

8. Franco Moretti, "The Slaughterhouse of Literature," p. 207.

9. Gellu Naum, Filonul (The Lode), Editura Tineretului, 1952, p. 31.

10. See also Simona Preda, Patrie Română, tară de eroi! (Romanian Homeland, Country of Heroes!), Curtea Veche, Bucharest, 2014, p. 25.

11. Eugen Negrici, Literatura română sub comunism. 1948-1964.

12. Ibid., p. 63.

13. Ibid.

14. Ibid.

15. Ibid.

16. Ibid., p. 69.

17. Ibid., p. 66.

18. Medvedeva, N., qtd. in Felicity Ann O'Dell, Socialisation Through Children's Literature: the Soviet Example, Cambridge University Press, 1978, p. 6.

19. Ibid.

20. Ibid., p. 7.

21. Ibid.

22. Ibid.

23. Marina Balina, L. Rudova, (eds.), Russian Children's Literature and Culture, New York, Routledge, 2008, p. 3.

24. Ibid., p. 4.

25. Belinskii qtd. in Balina, p. 4.

26. Dobroliubov qtd. in Balina, p. 4.

27. Vincas Auryla in Beckett, p. 177.

28. Ibid.

29. Ibid.

30. Eugen Negrici, Literatura..., p. 68.

31. Ibid., p.64.

32. Gellu Naum, Filonul, p. 4.

33. Ibid., p. 5.

34. Ibid., p.18.

35. Ibid.

36. Ibid., p. 20.

37. Ibid., p. 21.

38. Ibid., p. 29.

39. See also Simona Preda's analysis on the Soviet import of the ideology of "the new man" in communist Romania, in Patrie Română..., pp. 18-25.

40. Eugen Negrici argues that the central myths and themes of propagandistic literature have a strong religious component: "In a ceaseless attack, literature acted together with the press, schools, radio, the army and with any other imaginable institution in order the consolidate the communist ethos. In order to achieve this goal, it was recommendable to constantly reload, with small variations, some - very fewthemes and subjects, much like in the manner that, during religious sermons, celebratory formulas are continuously repeated. This pious exercise, involving thousands of genuflections and the utterance of repetitive formulas, the future soldiers were being taught the following dogma: the cult of sanctified martyrs (the soviet soldier as civilizing hero; the communist that sacrificed himself for our happiness), the cult of the apostles of the faith (Lenin, Stalin, Gheorghiu-Dej), the cult of the protective church (the Party), the cult of the heavenly kingdom - the paradise of the righteous (The Soviet Union), the cult of the new man, exorcised, atoned, redeemed by the righteous faith, vigilantly facing pagan temptations, the shameful past, the deceiving incarnations of the enemy, enjoying his awakening to a new life ('in cities and villages') and longing for beatitude, for the eternal life promised to the party faithful (communist heaven)" - Ibid., p.69. 
41. Gellu Naum, Filonul, p. 29.

42. Svetlana Cârstean, interview with Lygia Naum, "Whatever he does can only be beautiful," Observator cultural, March 11, 2003, available online http://www.observatorcultural.ro/articol/orice-face-el-nupoate-fi-decit-frumos-ii-interviu-cu-lyggia-naum/, accessed January $12^{\text {th }}, 2017$.

43. Gellu Naum, Tabăra din munți (The Camp in the Mountains), Bucharest, Editura Tineretului a C.C. al U.T.C., 1953, p. 20.

44. Ibid., p. 35.

45. Ibid., p. 115.

46. See Lucian Boia, Mitologia științifică a comunismului, Humanitas, București, 2006.

47. Pavlic Morozov is one of the martyrs of Soviet propaganda for youth, constantly praised for his heroic deeds in Soviet schoolbooks. He was believed to have denounced his father for having stolen part of the crop he had to give for requisition, in order to feed his family. As a result, his father was condemned to forced labor and then executed. His relatives are believed to have killed him, according to the communist version of the tale. The invocation of this iconic Soviet character strengthens the argument that Naum's book is heavily influenced by the Soviet paradigm of literature for children and youth.

48. Gellu Naum, Tabăra din munți, p. 172.

49. Ibid., p. 176.

50. Ibid., p. 125.

51. Ibid., p. 309.

52. Gellu Naum, Poem despre tinerețea noastră (The Poem of Our Youth), Editura Tineretului, 1960, p. 5.

53. Ibid., p. 7.

54. Ibid., p. 8.

55. Ibid.

56. Ibid., p. 10.

57. Ibid., p. 13.

58. The Union of Communist Youth (in Romanian, U.T.C., Uniunea Tineretului Comunist).

59. Gellu Naum, Poem despre tinerețea noastră, p. 16.

60. Ibid., p. 17.

61. Ibid., p. 20.

62. Ibid., pp. 23-24

63. Ibid., p. 26.

64. Ibid., p. 28.

65. Ibid., p. 32.

66. Ibid., p. 35 .

67. Eugen Negrici, Literatura română sub comunism, p. 71.

68. Ibid., p. 70.

69. Ibid.

70. Gellu Naum, Poem despre tinerețea noastră, p. 40.

71. Ibid., p. 42.

72. Gellu Naum, "Un singur lucru" (Only One Thing), in Soarele calm (Calm Sun), Bucharest, Editura Pentru Literatură (Literature Publishing), 1961, p. 7

73. Ibid., "Primăvara lumii" (Spring of the World), p. 8.

74. Ibid., p. 9.

75. Ibid.

76. Ibid., pp. 9-10.

77. Ibid., p. 10.

78. Ibid.,p. 12.

79. Ibid., p. 13.

80. Ibid., p. 14.

81. Ibid., p. 18. 
82. Ibid., p. 21.

83. Ibid.

84. Ibid., p. 23.

85. Ibid.

86. Ibid., p. 25.

87. Ibid., p. 26.

88. Ibid., p. 59.

89. Ibid., p. 65

90. Ibid., p. 69.

91. Ibid., p. 94. 